tween patients with BMI over or less than 50 . Despite low number of participants, we suppose that increasing of the study power will be not able to find differences between groups. Basing on this results, we may also suppose that undifferentiated (on the basis of $\mathrm{BMI}$ ) implementation of the enhanced recovery protocols does not carry risk increase for postoperative compli-

\section{References}

1. Clavien P. A., Barkun J., De Oliveira M. L., Vauthey J. N., Dindo D., Schulick R. D., De Santibanes E., Pekolj J., Slankamenac K., Bassi C., Graf R., Vonlanthen R., Padbury R., Cameron J. L., Makuuchi M. The ClavienDindo classification of surgical complications: five-year experience. Ann Surg 2009;250(2):187-196.

2. Elliott J. A., Patel V. M., Kirresh A., Ashrafian H., Le Roux C. W., Olbers T., Athanasiou T., Zacharakis E. Fast-track laparoscopic bariatric surgery: a systematic review. Updates Surg. 2013;65(2):85-94.

3. Hoffmann H., Kettelhack C. Fast-track surgeryconditions and challenges in postsurgical treatment: a review of elements of translational research in enhanced recovery after surgery. Eur Surg. Res. 2012;49(1):24-34.

4. Khatsiev B. B., Kuzminov A. N. Sleeve gastrectomy for morbid obesity - regional experience. Meditsinskii Vestnik Severnogo Kavkaza. - Medical News of North Caucasus. 2014;9(2):109-111. doi:10.14300/ mnnc.2014.09033 cations or complication severity in patients with high or extremely high BMI.

However, early humoral mechanisms of action of bariatric surgery limit the study results to the bariatric patients, and the results of enhanced recovery protocols implementation in extremely obese patients in non-bariatric surgery may differ and should be additionally studied.

5. Lemanu D. P., Srinivasa S., Singh P. P., Johannsen S., Maccormick A. D., Hill A.G. Optimizing perioperative care in bariatric surgery patients. Obes. Surg. 2012;22(6):979-990.

6. Lv L., Shao Y. F., Zhou Y. B. The enhanced recovery after surgery (ERAS) pathway for patients undergoing colorectal surgery: an update of meta-analysis of randomized controlled trials. Int. J. Colorectal. Dis. 2012;27(12):1549-1554.

7. Spanjersberg W. R., Reurings J., Keus F., Van Laarhoven C. J. Fast track surgery versus conventional recovery strategies for colorectal surgery. Cochrane Database Syst. Rev. 2011;(2):CD007635.

8. Varadhan K. K., Neal K. R., Dejong C. H., Fearon K. C., Ljungqvist O., Lobo D.N. The enhanced recovery after surgery (ERAS) pathway for patients undergoing major elective open colorectal surgery: a metaanalysis of randomized controlled trials. Clin. Nutr. 2010;29(4):434-440.

\footnotetext{
About authors:

Stavropol State Medical University, Russia;

tel.: +79283211335; e-mail: bkhatsiev@yandex.ru Russia; tel.: +79283296633; e-mail: dr.kuzminov@gmail.com

Khatsiev Bekhan Bayalovich, MD, PhD, deputy director of Clinic of endoscopic and minimally invasive surgery,

Uzdenov Nauruz Akhmatovich, MD, surgeon of Clinic of endoscopic and minimally invasive surgery,

Stavropol State Medical University, Russia; e-mail: bkhatsiev@yandex.ru

Kuzminov Alexander Nikolaevich, MD, surgeon of Clinic of endoscopic and minimally invasive surgery, Stavropol State Medical University,

\title{
EXPERIENCE WITH ESMERON IN DAY SURGERY IN CHILDREN
}

\author{
Nasibova E. M., Poluxov R. Sh.
}

\author{
Azerbaijan Medical University, Baku, Azerbaijan
}

\section{ПРИМЕНЕНИЕ ЭСМЕРОНА В ОАНОАНЕВНОЙ ХИРУРГИИ У АЕТЕЙ}

\author{
Э. М. Насибова, Р. Ш. Полухов
}

\section{АзербайАжанский меАицинский университет, Баку, АзербайАжан}

Monomioplegii idea - the use of one drug for the purpose of intubation and maintenance of neuromuscular blockade is an indisputable advantage of the one-day surgery. The authors have shown that the use of muscle relaxant esmeron enables abandon combined mioplegii succinylcholine and nondepolarizing muscle relaxants. The speed of response mioplegii average duration it indispensable in day surgery in children. The authors also note that mioplegii with esmeron more controllable and controlled, its use can significantly reduce the need for patients dekurarization or prolonged assisted ventilation. On the basis of clinical data and TOF-guard monitoring the application of the algorithm esmeron justified in surgical interventions in children.

Key words: esmeron, succinylcholone, one day surgery, children 
Идея мономиоплегии - использования одного препарата с целью интубации и поддержания миорелаксации, является неоспоримым преимуществом однодневной хирургии. Показано, что применение миорелаксанта эсмерона дает возможность отказаться от комбинированной миоплегии сукцинилхолином и недеполяризующими миорелаксантами. Быстрота развития миоплегического эффекта, средняя продолжительность действия препарата делают его незаменимым в однодневной хирургии у детей. Установлено, что миоплегия эсмерном более управляема и контролируема, ее применение позволяет значительно снизить потребность в проведении декураризации или продленной вспомогательной вентиляции. На основе клинических данных и TOF-guard мониторинга обоснован алгоритм применения эсмерона в оперативных вмешательствах у детей.

Ключевые слова: эсмерон, сукцинилхолин, однодневная хирургия, дети

W ith the development of anesthetic management requirements of muscle relaxants used in day surgery in children is getting tougher. Today, the ideal muscle relaxant should provide pronounced effect is the rapid onset of the blockade of neuromuscular transmission, have a short duration of action (control) did not cumulated in the body of the patient and not have a negative impact on the patient's body, and the introduction should not stimulate the release of histamine. These requirements correspond esmeron muscle relaxant [4]. Through the introduction of the practice esmeron an opportunity to abandon combined mioplegii succinylcholine and nondepolarizing muscle relaxants. The rapid development of its effect is due to the relatively low power and highly lipophilic drug that ultimately leads to more blocked cholinergic receptors and rapid development mioplegii. Currently, there is a clear desire to reduce the time spent by the patient after surgery in the hospital one day. Reduced hospital stay requires a rapid recovery of motor activity. At the same time, using anticholinesterase drugs for recovery of neuromuscular conduction is not always desirable in some patients, particularly those with underlying diseases of the cardiovascular system and lungs, as well as children $[6,9]$.

Despite the obvious benefits of modern non-depolarizing muscle relaxants (esmeron, cisatracurium besilate) in comparison with their predecessors, their use is not free of side effects and complications. Due to the relatively recent introduction esmeron the practice of pediatric anesthesiology, there is still no sufficient experience of its application and not adequate [2,5]. Some authors suspect influence of prolonged NM-block on septic complications after surgery [7]. Most researchers advice to recover block after surgery in all cases $[1,4]$.

Obyective: to study the effectiveness and safety of esmeron in day surgery in children, evaluation of conditions for intubation, monitoring of neuromuscular conduction, clinical assessment of the drug, the identification of possible adverse reactions and effect on hemodynamics.

Material and Methods. The work was carried out in the surgical clinic of the Department of Pediatric Surgery of Azerbaijan Medical University. The study included 65 children aged 1-15 years, after obtaining the voluntary consent of the parents in accordance with rules of GCP, who underwent elective surgery for inguinal and umbilical hernia, cryptorchism, varicocele, soft tissue tumors, tonsillitis and adenoids, foreign bodies of the esophagus and bronchoscopy, etc., the risk of anesthesia classification ASA I-II class. We were excluded patients with initial impaired liver and kidney function, with concomitant cardiovascular, pulmonary, neuromuscular disorders, decompensate diabetes. All patients were divided into three groups depending on the used type of muscle relaxant. Patients in group I $(n=20)$ was achieved by introducing miorelaxation succinylcholine in standard dosage of $2 \mathrm{mg} /$ $\mathrm{kg}$. In the other two gtoups controlled mioplegii conducted using esmeron in various dosages. In group II $(n=20)$ esmerone initial dose was $0.6 \mathrm{mg} /$ $\mathrm{kg}\left(2 \times E D_{90}\right)$, in group III $(\mathrm{n}=25)$ was used esmerone dose of $0.9 \mathrm{mg} / \mathrm{kg}\left(3 \times \mathrm{ED}_{90}\right)$. Selecting the starting dose used esmeron specify the intended duration of the operation. All children prior to surgery in the presence of their parents as a premedication intravenously administered propofol at the rate of $1.5 \mathrm{mg} / \mathrm{kg}$. Induction of anesthesia in general carried out either with the use of inhaled anesthetics (sevoflurane, isoflurane), using either intravenous anesthetic (propofol). Before intubation fentanyl administered intevenously $(2 \mathrm{mkg} / \mathrm{kg}$ ) followed by a 1-2 minute, study of muscle relaxants. Tracheal intubation was performed, focusing on the performance of the monitor neuromuscular conduction TOF-guard. Maintenance of anesthesia in all groups was carried out under the scheme isoflurane $1 \mathrm{~V} \%+$ fentanyl, or propofol+fentanyl. Mechanical ventilation was performed in the mode normoventilation $\mathrm{PetCO}_{2}(35-40 \mathrm{mmHg})$ with a ratio of inspiration:an expiration $(\mathrm{I}: \mathrm{E})=1: 2$. Indicators of pulse oximetry are $98-99 \%$. Maintenance of neuromuscular block (NMB) in groups II and III carried out repeated intravenous bolus esmeron $(0.15 \mathrm{mg} / \mathrm{kg})$. The reason for the introduction of a maintenance dose esmeron served $\mathrm{T}_{1}$ recovery to $25 \%$. At the end of the operation:the reduction to a level of NMB TOF $>70 \%$ and the presence of clinical signs of effective recovery of muscle tone (adequate spontaneous breathing, the opening of the eye, the retention of the head in an elevated 
state for 10 seconds, lifting and holding the four limbs) was performed tracheal extubation. Anesthetic performed using anesthesia machine Drager Fabius plus. Hemodynamic: heart rate on ECG and pulse oxmetry; non-invasive blood pressure (systolic, diastolic and mean), $\mathrm{SaO}_{2}$ were monitored using the monitor Bionet production in Germany and the partial pressure of carbon dioxide you exhale $\left(\mathrm{PetCO}_{2}\right)$ were recorded on a capnograph Capnostat. In order to assess the depth of neuromuscular block is dynamic control performance of neuromuscular block is dynamic control performance of neuromuscular conduction using akseleromiograf "TOF-guard». Terms of intubation was assessed according to the table proposed by R. Cooper (Table), taking into account the ease of laryngoscopy and vocal cord patient response to intubation.

Table

Assessment of the conditions of tracheal intubation (for R. Cooper)

\begin{tabular}{|l|c|c|c|c|c|}
\hline $\begin{array}{c}\text { Relaxation } \\
\text { the muscles } \\
\text { of the lower jaw }\end{array}$ & Points & $\begin{array}{l}\text { Condition } \\
\text { voice lig- } \\
\text { aments }\end{array}$ & Points & $\begin{array}{c}\text { The re- } \\
\text { sponse to } \\
\text { intubation }\end{array}$ & Points \\
\hline $\begin{array}{l}\text { Insufficient } \\
\text { (laryngoscopy } \\
\text { Impossible) }\end{array}$ & 0 & $\begin{array}{l}\text { are } \\
\text { closed }\end{array}$ & 0 & $\begin{array}{l}\text { Expressed } \\
\text { Cough } \\
\text { reflex, or } \\
\text { straining }\end{array}$ & 0 \\
\hline $\begin{array}{l}\text { Minimal } \\
\text { (laryngoscopy } \\
\text { difficult) }\end{array}$ & 1 & close up & 1 & $\begin{array}{l}\text { Moderate } \\
\text { Cough } \\
\text { reflex }\end{array}$ & 1 \\
\hline $\begin{array}{l}\text { Satisfactory } \\
\text { (laryngoscopy } \\
\text { teasible) }\end{array}$ & 2 & $\begin{array}{l}\text { Divorced } \\
\text { not fully }\end{array}$ & 2 & $\begin{array}{l}\text { A small } \\
\text { movement } \\
\text { of the dia- } \\
\text { phragm }\end{array}$ & 2 \\
\hline $\begin{array}{l}\text { Good } \\
\text { (laryngoscopy } \\
\text { Without diffi- } \\
\text { culty) }\end{array}$ & 3 & $\begin{array}{l}\text { Divorced } \\
\text { fully }\end{array}$ & 3 & No & 3 \\
\hline
\end{tabular}

Note: 8-9 points - excellent; $6-7$ points - well; 3-5 points satisfactory; 0-2 points - bad.

Results and Discussions. In group II patients studied $(0.6 \mathrm{mg} / \mathrm{kg})$ maximum neuromuscular block $\left(T_{1} 0.5 \%\right.$, TOF 0$)$ developed an average of $61.0 \pm 6.2$ seconds $(p<0.05)$. Even more rapid onset of complete neuromuscular block was noted in group III $(0.9 \mathrm{mg} / \mathrm{kg})$ and amounted to $41.5 \pm 4.2$ seconds $(p<0.05)$. Thus, the maximum neuromuscular block advancing significantly faster at higher doses esmeron, indicating dose-dependent effect of the drug and is consistent with the literature. When

\section{References}

1. Boer H. D., van Egmond J., Driessen J. J., Booij L. H. D. Update on the management of neuromuscular block: focus on sugammadex. Neuropsychiatr Dis Treat 2007 Oct; 3(5): 539-544.

2. Bonow F. P., Piva J. P., Garcia P. C., Eckert G. U. Assesment of intubation procedures of reference pediatric and neonatal intensive care units. J. Pediatr (Riol). 2004;80(5):355-362.

3. Driessen J. J., Robertson E., van Egmond J., Booij L. H. D. The time-course of action and recovery of rocuronium 0.3 using esmerone dose $0.6 \mathrm{mg} / \mathrm{kg}$ fixed minimum time to achieve full neuromuscular blockade -30 seconds, and maximum - 100 seconds. In a study of tracheal intubation was performed, focusing on the performance of the monitor neuromuscular conduction TOF-guard, upon the occurrence of the maximum block $\left(\mathrm{T}_{1}-5 \%\right.$, TOF $\left.0-4\right)$. Analysis of the conditions of intubation showed that tracheal intubation was possible using esmeron in all studied doses. Terms intubation at doses esmerone $0.6-0.9 \mathrm{mg} / \mathrm{kg}$ became excellent in $100 \%$ of cases. After the first administration esmerone dose of $0.6 \mathrm{mg} / \mathrm{kg}$ clinically effective duration of neuromuscular block (recovery of neuromuscular conduction time $\mathrm{T}_{1}$ to $25 \%$ ) remained $26.0 \pm 2.3$ minutes $(p>0.05)$. After loading dose esmeron $0.9 \mathrm{mg} / \mathrm{kg}$ effective neuromuscular block lasted an average of $43.2 \pm 1.3$ minutes $(p>0.05)$. The study showed that recovery index (time from $25 \%$ to $75 \%$ recovery of $\mathrm{T}_{1}$ ) was $12.1 \pm 1.3$ minutes in the second group $(0.6 \mathrm{mg} / \mathrm{kg})$ and $15.2 \pm 1.6$ minutes the third group of patients $(0.9 \mathrm{mg} / \mathrm{kg})$. We also found out in our research that the recovery of neuromuscular transmission in all cases there is a stable range between the maximum and minimum values are not exceeded 10 minutes and it talks about the predictability of recovery of neuromuscular conduction using esmeron. In our study, we also compared the start time and conditions of tracheal intubation when using succinylcholine and two different doses of esmeron. After the initial dose of succinylcholine $(2 \mathrm{mg} / \mathrm{kg})$ of the maximum block time $\left(T_{1} \quad 0-5 \%\right.$ was averaged $55.3 \pm 11.0$ seconds. We found no significant differences in the rate of complete neuromuscular block using succinylcholine ( I group) and esmeron at a dosage of $0.6 \mathrm{mg} / \mathrm{kg}$ (II group) and $0.9 \mathrm{mg} / \mathrm{kg}$ (III group). Also, the results of the study showed that at a comparable time, the start of the esmeron at doses of $0.6 \mathrm{mg} / \mathrm{kg}$ and $0.9 \mathrm{mg} / \mathrm{kg}$ provided better than succinylcholine conditions for tracheal intubation.

Conclusions. Esmeron when used in children provides a quick and effective offensive neuromuscular block.

Esmeron at doses of $0.6 \mathrm{mg} / \mathrm{kg}\left(2 \times E_{90}\right)$ and $0.9 \mathrm{mg} / \mathrm{kg}\left(3 \times E D_{90}\right)$ provides better conditions intubation than succinylcholine.

Application esmeron has no significant effect on hemodynamics without causing development of adverse effects and complications, suggesting its use in security day surgery in children.

mgákg in infants and children during halothane anaesthesia measured with acceleromyography. Paediatric Anaesthesia 2000;10:493-497.

4. Feltman D. M., Weiss M. G., Nicoski P., Sinacore J. Rocuronium for nonemergent intubation of term and preterm infants. Journal of Perinatology 2011;31(1):38-43.

5. Meakin G. H. Muscle relaxants in paediatric day case surgery. European Journal of Anaesthesiology 2001;18(Suppl 23):47-52.

6. Mixa V. Selective intubation in small children using the univemt tracheal tube. European Congress of Paedi- 
atric Anaesthesia. Abstracts for poster presentation 169, 2005.

7. Obedin A. N., Alexandrov A. E., Kirgizov I. V. et al. Intensive care of newborns with congenital abnormalities of gasrtointestinal tract and high risk of septic complications. Pediatric Surgery (Russ) 2013;(1):19-24
8. Vuksanaj D., Fisher D. M. Pharmocokinetics of rocuronium in children aged 4-11 years. Anesthesiology 2006;82:35-38

9. Wierda J. M., Meretoja O. A., Taivainen. T., Proost J. H. Pharmacokinetics and pharmacokinetic-dynamic modeling of rocoronium in infants and children. $\mathrm{Br}$. J. Anaesth 2005;78:690-693.

\title{
About authors:
}

Nasibova Esmira Mirza, MD, Associate Professor, Department of Pediatric Surgery, Azerbaijan Medical University, Azerbaijan; tel.: +994773366077; e-mail: Nasibova_esmira@mail.ru

Poluxov Ramiz Shamil, MD, Associate Professor, Department of Pediatric Surgery, Azerbaijan Medical University, Azerbaijan; tel.: +994503162699; e-mail: Ramiz Poluxov@mail.ru

\section{NECROTIZING ENTEROCOLITIS OF NEWBORNS. DO WE DO EVERYTHING TO SAVE OUR PATIENTS?}

\author{
Obedin A. N. ${ }^{1}$, Kachanov A. V. ${ }^{1}$, Annenkov M. V. ${ }^{2}$, Tovkan E. A. ${ }^{2}$, Kiriyenko O. S. ${ }^{2}$
}

1 Stavropol State Medical University, Stavropol, Russian Federation

2 Stavropol Regional Children's Clinical Hospital, Stavropol, Russian Federation

\section{НЕКРОТИЧЕСКИЙ ЭНТЕРОКОАИТ НОВОРОЖАЕННЫХ. ВСЁ АИ МЫ АЕААЕМ ААЯ СПАСЕНИЯ СВОИХ БОАЬНЫХ?}

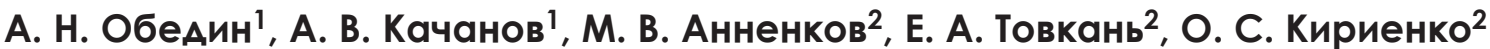 \\ 1 Ставропольский госуаарственный меАицинский университет, Ставрополь, \\ Российская ФеАерация \\ 2 Краевая Аетская кАиническая больница, Ставрополь, Российская ФеАерация
}

The aim of the study was to compare the efficacy of anesthesia in infants with NEC presacral during anesthesia with different preparations.

We were treated 19 infants with NEC from 1B to 3A stages, during the double-blind controlled prospective randomized study and the period from 2012 to 2014 . Boys were 12, girls -7 . Body weigh was $1996+0.2$ gramms. The group 1 of 10 infants was assigned the complex treatment technique, developed by us, presacral anesthesia $0.5 \%$ sol. ropivacaine of $0.1 \mathrm{ml} / \mathrm{kg}$. The group 2 was 9 infants, was assigned with the traditional methods of complex intensive care the blockade of procaine solution $0.25 \%$ the rate of $0.5 \mathrm{ml}$ per administration. Determined by the concentration of substance $\mathrm{P}$, cardiac output and peripheral vascular resistance at diagnosis, after 2,4,8 and 16 hours after initiation of treatment. Assessed the extent and severity of pain on a scale CHEOPS. The control group consisted of 20 healthy newborns without evidence of NEC.

After 16 hours from the start of treatment, despite the additional analgesic therapy was undertaken in a group 2, level of pain on a scale CHEOPS was significantly higher than in the same period of observation in the group 1 . It was $9.5 \pm 0.2$ and $6.0 \pm 0.5$ points, respectively, with $p=0.001$. The concentration of substance $P$ in serum of blood of newborns with NEC corresponded to the severity of pain and was significantly higher in the group 2 compared to the group 1 to 16 hour of therapy.

Presacral analgesia with ropivacaine is more efficiently and reduces the number of surgical interventions in newborns with NEC probably by reducing circulatory disorders of internal organs and systems.

Key words: necrotizing enterocolitis, treatment, anesthesia, pain, scale CHEOPS, newborns

Рассмотрена проблема лечения новорожденных с некротическим энтероколитом (НЭК). Пациенты были случайным образом распределены на две группы, сопоставимые по гестационному возрасту, весу и полу. Первую группу составили 10 новорожденных с НЭК 1-3 стадии, у которых в комплексе лечения проводили пресакральные блокады с ропивакаином. Вторая группа была представлена 9 пациентами с НЭК 1-3 стадии, которым проводили пресакральные блокады с прокаином. Определяли концентрации субстанции Р в пуповинной крови, сердечный выброс и перифери- 